\title{
Troll: Issues Discussed Using Meme in Mid-2018
}

\section{Faizul Nizar Anuar, Fauziah Ahmad \& Sabariah Mohamed Salleh}

To Link this Article: http://dx.doi.org/10.6007/IJARBSS/v11-i17/11397 DOI:10.6007/IJARBSS/v11-i17/11397

Received: 06 August 2021, Revised: 11 September 2021, Accepted: 25 September 2021

Published Online: 12 October 2021

In-Text Citation: (Anuar et al., 2021)

To Cite this Article: Anuar, F. N., Ahmad, F., \& Salleh, S. M. (2021). Troll: Issues Discussed Using Meme in Mid2018. International Journal of Academic Research in Business and Social Sciences, 11(17), 127-151.

\section{Copyright: (C) 2021 The Author(s)}

Published by Human Resource Management Academic Research Society (www.hrmars.com)

This article is published under the Creative Commons Attribution (CC BY 4.0) license. Anyone may reproduce, distribute, translate and create derivative works of this article (for both commercial and non-commercial purposes), subject to full attribution to the original publication and authors. The full terms of this license may be seen at: http://creativecommons.org/licences/by/4.0/legalcode

Special Issue Title: Empowering Community and Beyond, iRandau, 2021, Pg. 127 - 151

Full Terms \& Conditions of access and use can be found at http://hrmars.com/index.php/pages/detail/publication-ethics 


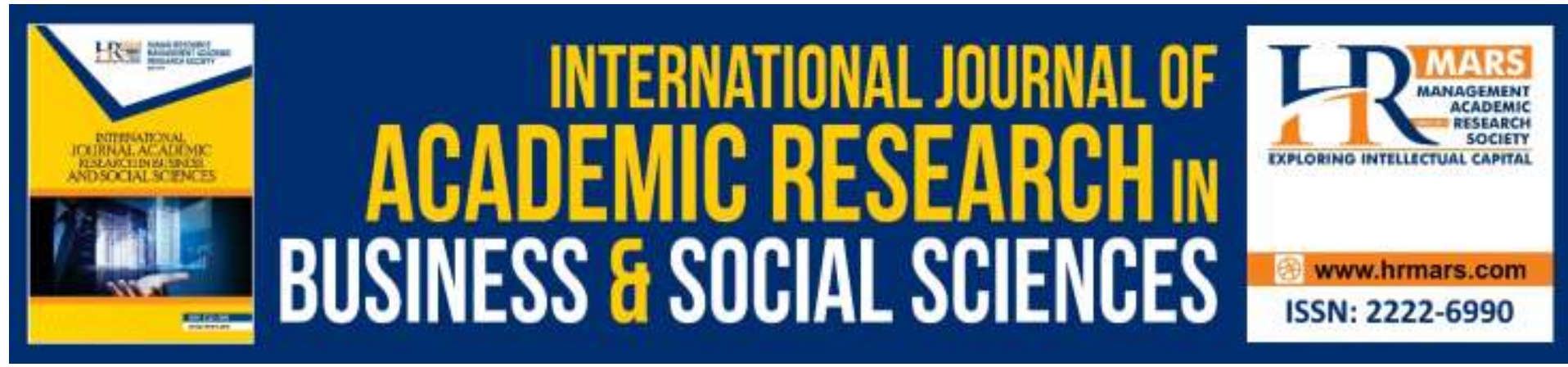

\title{
Troll: Issues Discussed Using Meme in Mid-2018
}

\section{Faizul Nizar Anuar ${ }^{1}$, Fauziah Ahmad ${ }^{1}$ \& Sabariah Mohamed Salleh²}

${ }^{1}$ Department of Social Sciences and Management, Universiti Putra Malaysia Bintulu Campus, Sarawak, Malaysia, ${ }^{2}$ School of Media and Communication Studies, Faculty of Social Sciences and Humanities, Universiti Kebangsaan Malaysia

Email: nizar.anuar@upm.edu.my

\begin{abstract}
Text is polesemic, where a text is able to convey various meanings. Therefore, each individual will have different interpretations and opinions on something he or she experienced. Since a text can have a variety of meanings, therefore people may have different perceptions on the issues portrayed in memes. This study focuses on the Troll: Issues discusses using Meme in Mid 2018. Memes sharing on social media will lead to meaning construction for the reader. The objective of this study is to identify the issues discusses using meme in Mid-2018. A total of 30 types of memes were analysed using content analysis method. All meme samples were taken from the Facebook account of Si Rashid and Gags Malaysia during a period of three months from 1 May 2018 to 30 July 2018. The theory used as the analytical concept is the Media Dependency Theory by Ball-Rokeach and DeFleur. The results of the study found that the issues discussed using meme in 2018 focusing on the 14th General Election (GE-14), World Cup 2018 Hari Raya Aidilfitri Celebration. Some people will depend on media when a current issue arises for example during times of turmoil, crisis or natural disaster. An individual will rely on media to obtain the latest information on something that is happening. This situation can be attributed to the production of memes that widely shared through social media when an issue occurs inside or outside of the country.
\end{abstract}

Keywords: Troll, Issue, Meme, Social Media, Facebook

\section{Introduction}

The existence of technology and communication media has greatly facilitated human beings to interact with each other. Regardless of whether it is print media, electronic media or new media (Internet), the existence of all these types of media have indeed brought many benefits and facilitated the community to obtain the latest information and news more quickly and effectively (Mustafa \& Hamzah, 2010). The development of communication media and mass media today has undergone many processes of change and improvement. The revolution taking place to some extent has brought people to live in a more advanced manner and have high competitiveness in producing better quality work or products (Malaysian Administrative Modernisation and Management Planning Unit, 2015).

This situation can be attributed to the presence of various types of platforms which facilitate humans to interact and share the latest information, such as the internet and social 
media. According to Bhardwaj, Avasthi \& Goundar (2017), social media through uploaded content such as photos, videos, and even memes can have positive or negative impact on users. The positive effects are in terms of education, politics, awareness of its use, social advantages and being able to provide employment opportunities. On the other hand, from a negative point of view, they think that social media can lead to detrimental effect in terms of secrecy, leading to various forms of crime and causing a waste of time. According to Shifman (2014), the meme phenomenon is a process of formation of information content such as pictures produced through the process of imitation using technology. This form of content is then shared through social media platforms and so on. According to Ryan (2012), society produces pictures and videos by including additional elements such as sentences or certain words to describe an issue or event that occurs. Sentences and words included in a picture or video are sometimes imitated and designed deliberately to create an element of humor or sarcasm as stated by sociologist Prof Datuk Dr. Mohammad Shatar Sabran in Harian Metro on 16 January 2016. There are various types of memes, among them in the form of image memes (Foster, 2012), video memes (Shifman, 2011) and audio memes (Dawkins, 1976; Serazio, 2008). Some memes are produced in parody to raise an issue that needs to be highlighted. In this paper, researchers are interested in looking at the issues discussed using memes in mid2018. Like other media, memes also have the potential to give a lot of meaning to readers. There are many studies conducted related to memes, both in Malaysia and abroad. Yet in this case, researchers will focus on issues discussed using memes in mid-2018 only.

\section{Troll}

According to Kamus Dewan Bahasa dan Pustaka translation, troll in the Malay language means 'mengail tunda' literally translated as fishing or trawling. This situation can be attributed to the actions of netizens who share information and content whether in the form of sentences, videos, pictures, caricatures or graphics. According to a report in Berita Harian Online dated 27 January 2021, the purposes of trolls are more likely to be negative, such as to incite, spread untruths, sow hatred, and smear the dignity of an individual who becomes a victim of trolls.

\section{Issue}

Issue refers to the main thing, the question; important matters discussed in the conference (Kamus Dewan new edition). In this study, the issues discussed in the meme will be dissected to identify the topic and essence of the discussion being conveyed in a produced meme.

\section{Meme}

According to Shifman (2014), meme means to imitate or exaggerate a sensational issue that eventually goes viral in mass media such as social media and so on. According to him, there are some special features of memes, among them are the sharing of characters either in terms of physical or word, produced through the process of imitation and shared using technology and able to provide awareness and advice to readers. According to Anuar, Ahmad and Salleh (2017), the presence of memes aims to mock, ridicule, joke or insinuate, for example issues related to the political system and government in Malaysia. Dawkins (1976) outlined several examples of memes that have existed, among them are memes through melodies, catchphrases, fashion and also through technology. The existence of Internet memes is seen as information that is shared either in the form of macro images, videos and emails (chain emails) that use technology to facilitate its dissemination. In this study, only memes in the form of pictures were studied. 


\section{Social Media}

Social media is one of the communication media with the ability to bridge the relationship between all levels of society, without any restriction or obstacle. The existence of social media lately is seen as booming and widely used. There are various types of social media being introduced to make it easier for a person to socialize, whether to get new acquaintances, share interests, feelings and so on. Mustafa and Hamzah (2010) stated that the history of the emergence of social media began in 1997 with the presence of the SixDegree.com site containing special features such as profiles, friends and even specific messages. They also argued that, in 2000, social media have grown with the presence of business social media such as Ryze.com and Linkedln.com. A few years later, social media users were introduced to several new social media such as Friendster, MySpace and more. According to Lauren, Moira and Steven (2016), in addition to sharing information, the purposes of some users using social media are to gain a high number of Likes and attract attention from friends on the social media account used. The high number of Likes will reflect the large number of followers as well as the high influence of the social media account. Therefore, it is not surprising if the phenomenon of memes is seen to be more widespread on social media either to channel information and content, or to get more attention from followers.

\section{Facebook}

In 2008, the development of social media is seen to be growing tremendously with the existence of platform such as Facebook. According to Barthel et al. (2015), they found that reports of internet usage among the community in America showed that there were approximately 40 percent of citizens in the United States who obtained information and content through social media such as Facebook. On the other hand, MySpace changed its features specifically to music as well as movies. Meanwhile, Friendster was seen to have become increasingly popular in Southeast Asia. Nevertheless, the existence of Facebook is still getting response and attraction from users in the mass media even among the netizens nowadays.

\section{Research Background}

Aswati (2007) stated that the development of technology and globalization that hit this century has indirectly led to Western lifestyles are becoming more common in the Malay community. This phenomenon brings a big impact in everyday life and culture of the Malays so that they can lead to the destruction of the system of values and morals in the various layers of the society. As a result, more and more French people nowadays are reported to have been involved with various social problems related to behavior and character. This situation is of great concern to all parties. In the meantime, Tamuri and Ismail (2009), states that the proliferation of technology and the explosion of the negative contents of the mass media, whether from within or outside the country, has a lot of threat to Malay Muslim teenagers nowadays. Given the rapid development of modern technology, mass media such as the internet is considered one of the most influential factors on the development of adolescents in urban and rural areas, for example through the existence of memes, users will be exposed to sources of information and information content that is not true and has been manipulated. As consumers, they should be smarter and always sensitive to every piece of information that has been obtained so as not to fall victim to the situation or be deceived by the source of information read, for example through memes. 
In addition, the youths are also seen to be more easily influenced by something either through observation or what they listen to. This influence is getting stronger with the increasingly sophisticated technology today. This situation has given a great challenge to a consumer to use a media properly and more ethically. This problem is often associated with adolescents because adolescents are among the most active in using technology that has existed today. Therefore, it is not surprising that there are various negative symptoms related to the actions and behaviors of adolescents reported lately. Bedu et al (2008) stated that every day, issues and social symptoms involving hot teenage girls are discussed in the press and other mass media. This situation has indirectly given a clear picture that some teenage girls are now increasingly aggressive, bold, and wild. Many academic studies have been conducted by those with extensive knowledge in this field, whether directly or indirectly involved with adolescent issues such as ministries, departments, agencies, associations and non-governmental organizations (NGOs) and others. According to Bedu et al (2008), the problems of adolescents are related to the community environment, family, religious knowledge, education level, home environment, outside influences, media, entertainment, identity, friends and others another. Therefore, a user should be wise to make an assessment of the memes that have been read.

\section{Problem Statement}

The presence of information content generated on social media is seen to be springing up like mushrooms after the rain. Meme-shaped information content brings many benefits to readers. Through memes, readers can find out about current issues that are happening both locally and abroad. Information content in the form of memes is seen as an option among the youths to discuss a current issue that is happening, for example issues related to politics and so on. Although the meme produced has the element of humor, its presence is seen as very significant in conveying information more easily and effectively.

However, there are also some memes which are shared that may bring about negative impact on the audience. Some memes are produced by inserting additional elements that sometimes do not reflect the reality. The resulting meme is intended to mock. In addition, there are also memes produced intended to mock other individuals. Berita Harian dated 27 January 2019 reported that, social media is used as a platform to express feelings, disputes, emotions, and dissent against a handful of politicians. This condition can be attributed to the act of 'trolls'. According to Sangeet Kumar (2015), the presence of subversive forms of politics that imitate and distribute meme content has had an impact on social movements around the world.

According to Laine and Laura (2014) in the United States presidential election in 2012, memes were used as a virus to draw the attention of major news channels in relation to the candidates running. This situation shows that memes have been used as one of the mediums to influence the thinking of the people in making choices and voting for candidates in an election. Production techniques and meme content are seen to be able to influence a person's thoughts and actions in making choices. The same thing happened in Malaysia in the last 14th general election, where most of the memes produced during the period featured pictures of candidates contesting in the election. However, it is distressing to find there were a handful of people who deliberately produced and shared memes which carried untrue messages with the intention of tarnishing the reputation of a candidate. The situation was to some extent able to influence the thoughts and actions of voters. 
Sohana (2016) found that the use of a mass media is influenced by differences in thought patterns, differences in nature as a result of attitudes, social relationships and also differences in cultural forms. The situation ultimately affects a person's view of things, lifestyle and culture in a nation. Differences of opinions and views being pointed out above can be linked to the production of information content in the form of memes to voice opinions on a current issue which occurs. According to David et al (2018), the production of memes containing untrue information is seen as very worrying nowadays. He stressed that fake news is news content that overlaps between misinformation (wrong and misleading information content) and disinformation (wrong information content presented to deceive someone). According to Richard et al (2018), the distribution of false information (fake news) is seen to be increasingly worrying in most countries in recent years. There are some media users who accept news or information without first researching the truth of the content they read. Therefore, this study focused on issues which went viral using memes in mid-2018.

\section{Research Methodology}

This article discusses the results of the study findings from the content analysis conducted. A total of 30 types of memes were analyzed using content analysis method. All meme samples were taken from the Facebook account of Si Rashid and Gags Malaysia during a period of three months from 1 May 2018 to 30 July 2018. The selected memes consisted of the five memes that got the most number of likes (Top 5) during that period. Content analysis is a qualitatively performed method. Researchers are confident that by using this method, a clearer picture of the content of the meme can be provided.

There are four aspects that have been emphasized by researchers in the content analysis conducted, namely in terms of color, character, typography (font type and design), and layout. All the aspects listed will make it easier for researchers to explain and observe the implicit and explicit meanings being conveyed about an issue, through the use of memes. Content analysis is a method that has been widely used among researchers, including to see the level of sensitivity of a text, document or report (Rashidi et al., 2014). Suzan, Jane \& Terry (2018) stated that content analysis is a process of analysis performed on data obtained from various sources or case studies such as experiences, life stories, interviews, observations, history, interaction processes and text in the form of pictures which can give certain meaning to an individual. Moreover, he also argued that most of the studies conducted using content analysis methods will focus on text analysis. Furthermore, Suzan et al (2018) also stated that the content analysis method provides many advantages, including being able to provide opportunities for researchers to be closer to the data, more systematic, as well as having a specific time frame. All the advantages listed are the justifications and reasons why the researchers chose the method of content analysis to be applied in this study.

The total number of followers for Si Rashid's account was 652,602 people. Meanwhile, the number of followers for Gags Malaysia's account was 535,419 people. The high number of followers shows that the two accounts have indeed received attention from users on Facebook social media. In total, a total of 30 types of memes were obtained and sampled for this method, namely 15 types of meme samples from Si Rashid's account and 15 other types of meme samples from Gags Malaysia's account. All the memes were the five memes that received the most number of likes (Top 5) for each month from May 2018 until July 2018. The justification for selecting the five memes with the most likes for each of the three months is to get the most attention and selection from the recipients. Table 1 below shows the 
breakdown of the number of memes according to the Facebook accounts of Si Rashid and Gags Malaysia.

Table 1: Breakdown of total meme samples from May 2018 to July 2018

\begin{tabular}{lcccc}
\hline Account & $\begin{array}{c}\text { Total of Meme Samples } \\
\text { (May 2018) }\end{array}$ & $\begin{array}{c}\text { Total of Meme } \\
\text { Samples } \\
\text { (June 2018) }\end{array}$ & $\begin{array}{c}\text { Total of Meme } \\
\text { Samples } \\
\text { (July 2018) }\end{array}$ & Total \\
\hline Si Rashid & 5 & 5 & 5 & 15 \\
Gags & 5 & 5 & 5 & 15 \\
Malaysia & & & & $\mathbf{3 0}$ \\
\hline
\end{tabular}

\section{Theory}

Media System Dependency Theory was introduced by Ball-Rokeach and DeFleur in 1976. Based on this theory, an individual will feel their daily tasks are incomplete if they do not surf the internet or read the newspapers. This theory explains that consumers will depend on a medium to obtain the information they need. The situation that occurs highlights the issue of dependence on social media. This theory explains that the media plays an important role in channeling the information desired by an individual or in a large group.

According to Mehrad and Yousefi (2018), dependence on media will be clearly visible during a crisis, unrest or disaster. This condition can be attributed to media such as newspapers, magazines, books and so on. Shahrul and Nawwar (2017) argued that today's society is more sensitive and intelligent in evaluating the content of information that they obtain either by seeing, hearing or reading. This situation can be proven through the actions of some individuals who choose to be in front of the television screen to get the latest news related to an outbreak of a disease, natural disaster and so on. This theory is also seen to be able to change a person's level of knowledge about something. Figure 1 below shows the media system dependency model by Ball-Rokeach and DeFleur 1976. 


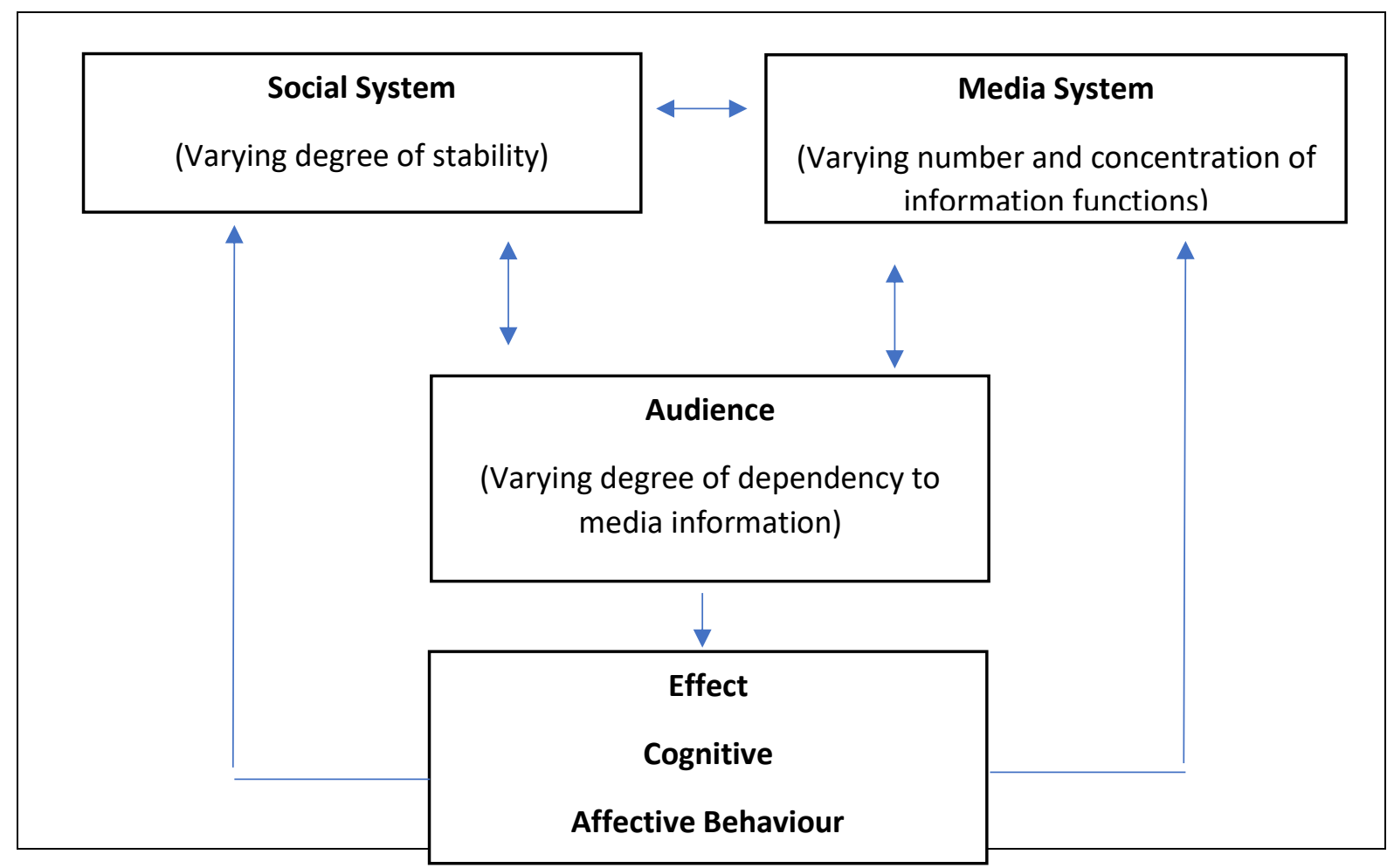

Figure 1: Media system dependency model by Ball-Rokeach and DeFleur 1976

Source: McQuail and Windahl 1993: 112

\section{Research Framework}

This paper focuses on viral issues using memes in mid-2018. To take a deeper look at the focus of this study, researchers have produced a sketch of a conceptual framework to clearly explain the scope and limitations of the study conducted. In this study, social system can be linked to culture, religion, politics, family system, economy, education and ideology which serve as independent variables. Social systems can be associated with the lifestyle of an individual, group, or society. This situation can be attributed to current issues that are happening both locally and abroad. Media systems refer to the technology used in the production of information such as Photoshop and Illustrator applications and so on.

In this study, the media system refers to the memes shared through the social media of Facebook and Gags Malaysia from May 2018 to July 2018. Among the aspects emphasized in this study are color, character, words and layout of a meme. This study focuses on issues spread using memes. The media system described is a dependent variable in this study. Figure 2 below shows the framework of the study for Troll: Issues discussed using memes in mid2018. 


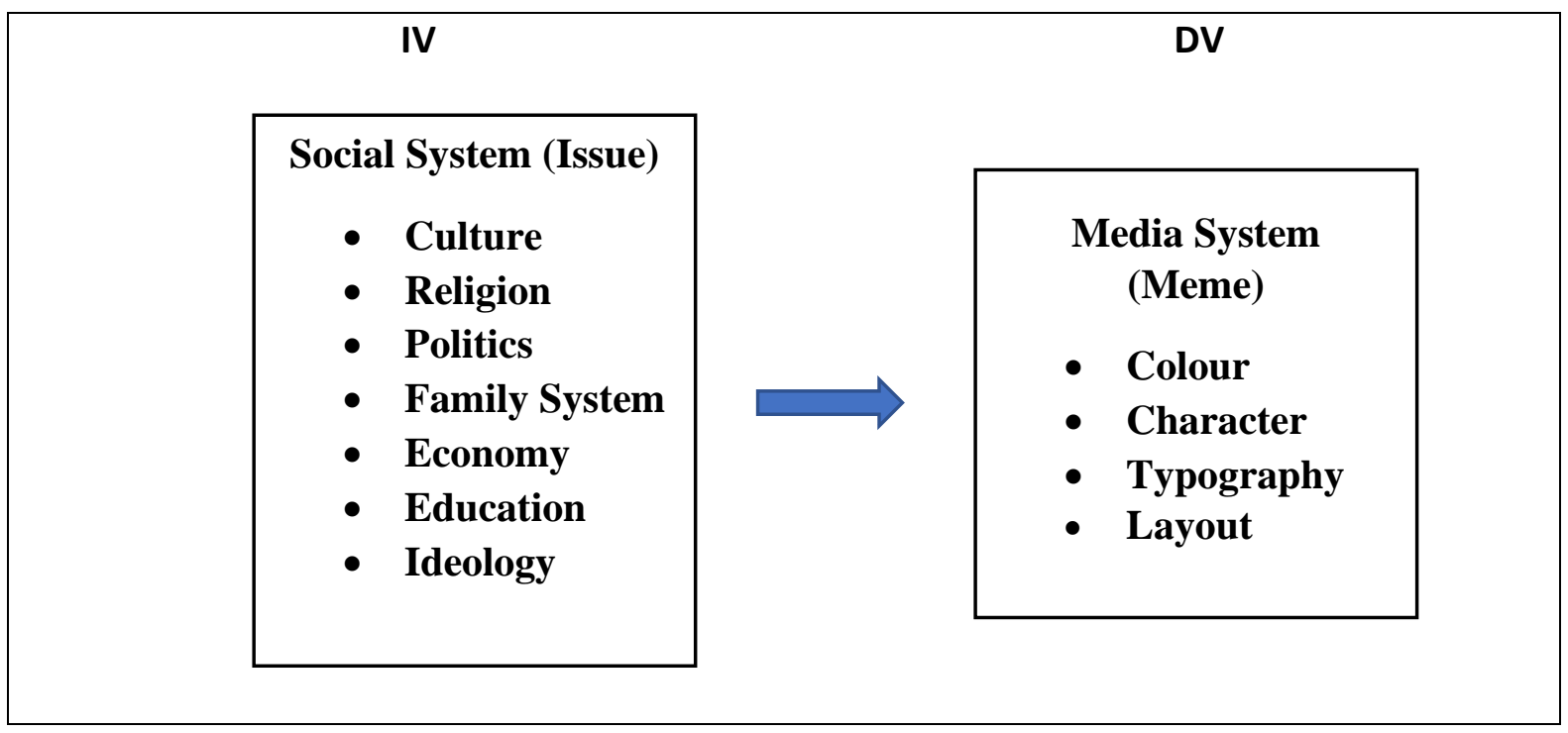

Figure 2: Research framework of Troll: Issues discussed using memes in mid-2018

\section{Issues Discussed Using Meme}

Based on the results of the study, the researchers found that most of the memes analyzed during the period told the story of hot current issues that were happening, such as political, sports and festive issues. The followings are some of the issues that have been successfully identified by researchers through a sample of memes analyzed using content analysis methods.

\section{The Issue of the 14th General Election (GE-14)}

The 14th Malaysian general election was held on 9 May 2018, on Wednesday. During that period, various types of memes were seen to have touched on political issues involving the parties contesting in the GE-14. Among the political parties involved in the election were Pakatan Harapan (PH), Barisan Nasional (BN), and Parti Islam Se-Malaysia (PAS). Based on the sample of memes analyzed, the researchers found that several issues were spread using memes. One of them was the issue of support in the campaign election.

This particular issue could be seen through various ways done by supporters of each political party contesting, including by conducting demonstrations and campaigns as a sign of support for the party. In addition, another issue related to GE-14 was the results of the election. Some parties were seen criticizing the election results. Some of the followers of certain parties felt that the final result obtained was due to the actions of voters in making the right choice in the GE-14 that took place. On top of that, researchers also found that GE14 issues could also be linked to influential politicians. In GE-14, one of the political party candidates most associated with memes was Tun Mahathir Mohamad who represented the Pakatan Harapan political party coalition. Apart from that, GE-14 issues were also often linked to Datuk Seri Najib Abdul Razak who represented the Barisan Nasional party coalition. Intense competition between the two-party candidates had led to the existence of various types of memes which painted some insights in relation to the competition.

There were also issues portraying the disappointment of followers of a losing political party. The defeat left many supporters of the party downhearted and some shed tears when they had to accept the defeat. The change of government was seen to have a profound effect on the supporters of the political parties contesting in GE-14. To identify issues related to the 
GE-14, several elements were used by researchers in the analysis of content, namely colour, character, typography and layout. Based on the content analysis, the researchers found that memes samples during the period used colour elements to symbolize the political parties they supported. The official colour of a political party was often chosen in memes. This situation can be observed through the use of green in the meme sample to refer to the Pan-Malaysian Islamic Party (PAS).

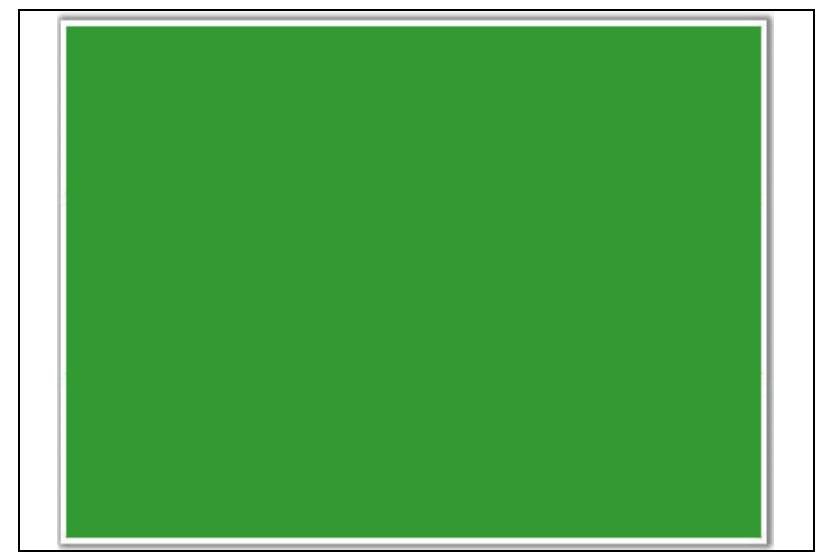

Figure 4.1: Green Color

The use of green could also be seen through the color of the flag for the contesting political parties. The flag of the political party that was often chosen during the period was the flag of the Pan-Malaysian Islamic Party (PAS). Based on the meme sample, the use of green could be observed through the color of the clothes worn by the party supporters. Apart from that, the clothes and flags used by the party supporters also contain the white moon symbol as shown in Figure 4.2 below.

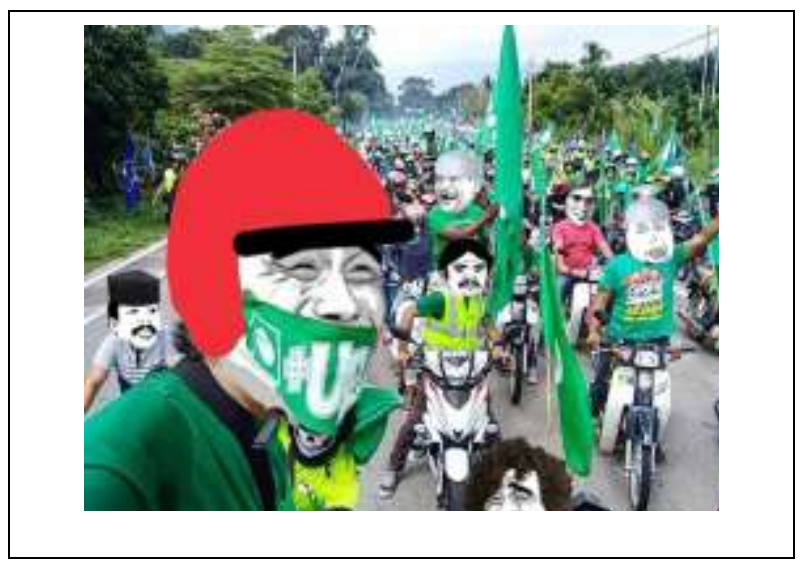

Figure 4.2: The issue of PAS party supporters in GE-14

The meme sample showed the party supporters holding a street demonstration while wearing green shirts. Green is the official color in the PAS party flag and is seen as a symbol and identity for the party's supporters and followers. The use of color is able to symbolize agreement and understanding between each of its members. Other than that, the use of color elements can also be seen through the color of the attire used by the character Oprah Winfrey as in Figure 4.3 below. 


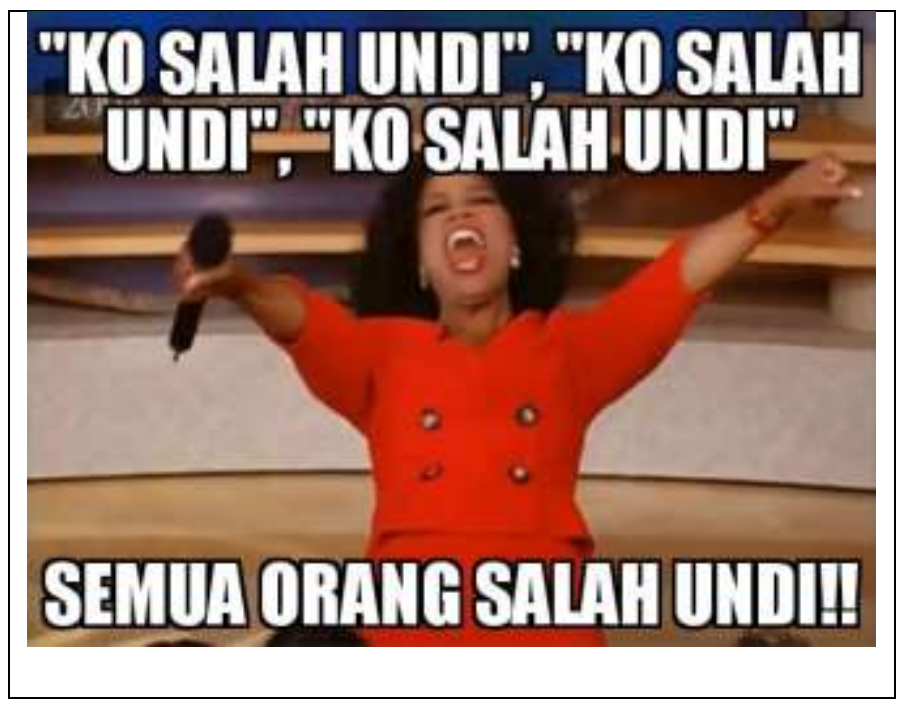

Figure 4.3: The issue of GE-14 results

Based on the meme sample, the image of Oprah Winfrey is wearing a red dress to make the meme more attractive and noticeable. However, behind the choice of the color red, there is an implicit meaning that is meaningful to describe the current political situation happening during GE-14. According to Lindgren and Jennifer (1997), the color red means willingness to accept a given challenge, reflecting bold action, able to show power and in turn symbolizing a form of swift action. This situation shows that the color red is a color that can reflect the courage of a person in criticizing the results of the General Election. This situation shows that the color red can also be associated with the current issue which occurred, namely GE-14 as shown in Figure 4.3 above. In addition, character elements can also be seen through the samples of memes studied. The use of character elements can be linked to the use of the 'motorcycle' symbol as symbolic to the support of young people as in Figure 4.2 shown earlier. This situation can be seen by the display of images of PAS supporters consisting of young people marching while riding motorcycles.

For researchers, the use of the 'motorcycle' symbol might be intended to prove that the PAS party does not only consist of the elderly or aged, but also has strong support from the younger generation. Apart from that, the memes studied during the period also often featured the characters of politicians contesting in the GE-14. Among the characters often displayed were the characters of national leaders such as the seventh Malaysian prime minister, Tun Mahathir Mohamad, and the sixth former Malaysian prime minister, Datuk Seri Najib Abdul Razak, as shown in Figure 4.4 below. 


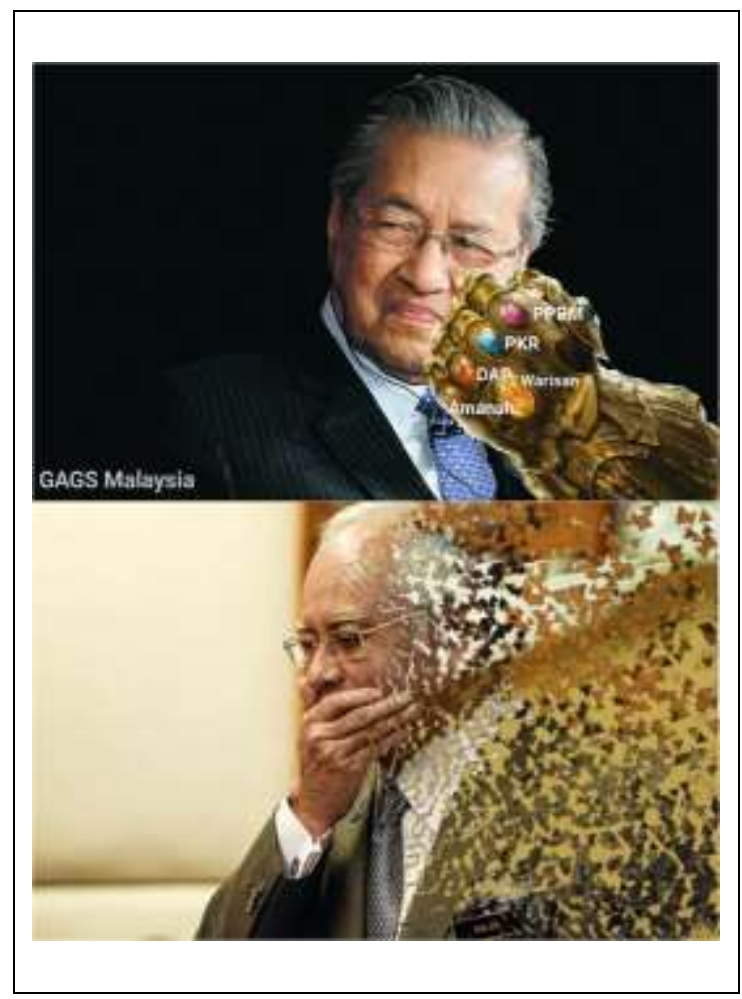

Figure 4.4: The issue of competition between Tun Mahathir Mohamad and Datuk Seri Najib

Apart from that, there are also memes studied which feature the images and characters of other politicians in Malaysia. All the characters were loaded in the form of memes to be displayed to the general public to raise issues related to GE-14. Based on the meme sample in Figure 4.4 above, the researcher identified the use of character element displaying the image of Tun Mahathir Mohamad. His character in the meme was edited where an image of Thanos Thor's hand was inserted on his left-hand side. The meme is showing as if he was using Thor's hand. Thanos Thor is one of the great characters found in western movies, namely Avengers: Infinity War. The film was screened on 23 April 2018, two weeks before the GE-14. The excitement of the film was indirectly linked to the political situation in Malaysia at the time, which was the 14th general election to elect a new government and people's representatives. Tun Mahathir's victory in the GE-14 had succeeded in reflecting his greatness, thus it was associated with the great character Thanos Thor in the film. Tun Mahathir's success was seen as a great victory when he successfully controlled and managed several contesting political parties such as Parti Pribumi Bersatu Malaysia (PPBM), Parti Keadilan Rakyat (PKR), Parti Tindakan Demokratik (DAP), Parti Warisan Sabah (Warisan) and Parti Amanah Negara (Amanah).

Other than that, the meme sample in Figure 4.4 also features the character of the sixth former prime minister of Malaysia, Datuk Seri Najib Abdul Razak. His image and face appeared to be looking dejected to reflect his defeat in the GE-14. Researchers also noted that Datuk Seri Najib's image was covering his mouth with his right hand as if he was not able to accept his defeat in the election. The meme sample was also edited by showing half of his face cracked and shattered like a broken and shattered glass surface. His image also seemed increasingly blurred and less clear. This circumstance was intended to give the meaning that his power and reign had already come to an end. Not only that, the support and trust given by Malaysians before this were also declining as were his image and character in the meme 
sample. In addition, samples of memes obtained during the period were also evaluated through typographic elements. Typography refers to the selection of font types and designs used in meme samples. The selection of font type and design is intended to help the reader understand the implied meaning in a meme. The selection of the appropriate and accurate font type and design will make it easier for the reader to more clearly understand each message conveyed in a meme. The use of typography can also be associated with the use of capital letters to refer to the initials of the contesting political parties, for example PAS to refer to Parti Islam Se-Malaysia, UMNO to refer to United Malays National Organization, PH to refer to Pakatan Harapan, BN to refer to Barisan Nasional, PPBM to refer to Parti Pribumi Bersatu Malaysia, the acronym PKR to refer to Parti Keadilan Rakyat, DAP to refer to Democratic Action Party, Warisan as the acronym for Parti Warisan Sabah and AMANAH to refer to Parti Amanah Negara. Most of the party names are attached in the form of word abbreviations using capital letters as shown in Figure 4.5 below.

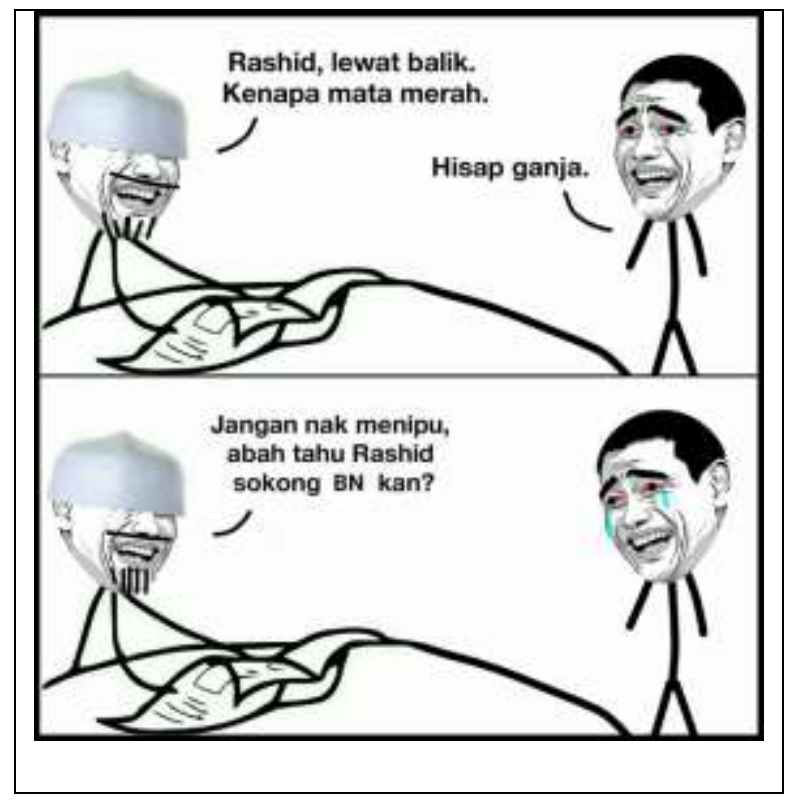

Figure 4.5: The issue of Barisan Nasional support in GE-14

Typographic elements are also associated with the font size and font color used in the meme samples studied. This situation is intended to ensure that the message conveyed is clearer for the audience to comprehend. Based on Figure 4.5 above, the researchers found that the word size used is large and makes it easier for the reader to understand the content and information being conveyed. Researchers also found that the use of word size is balanced and even. This is because, there are some samples of memes obtained during that period which used varying font sizes. In addition, the choice of font color is also given important emphasis. The researchers found that most of the selected meme samples used white in their production, for example as can be seen in the meme samples in Figure 4.3 and 4.4 shown previously. The color white was chosen because of its ability to highlight the message and words that want to be produced. Furthermore, the selection of white letters also made it easier to pair with a background that has a wide variety of colors. This situation will indirectly make it easier for the reader to understand the underlying message.

In terms of layout, the researchers found that most of the meme samples were arranged in an organized and orderly manner to make it easier for readers to understand each issue being presented. There are some samples of memes arranged according to the 
sequence of scenes such as comics to make it easier for readers to follow the story or issues, for example the GE-14 issue as in Figure 4.5 shown before. To explain the layout element in more depth, researchers conducted content analysis by looking at some of the features in the CASPER principle. This principle is often emphasized in explaining the concept of layout in multimedia as described previously. Based on the CASPER principle, there are several prominent features, such as Contrast, Alignment, Simplicity, Proximity, Emphasis, and Repetition. Based on the sample of memes studied, the researchers found that Contrast element was used to provide the difference between the first half (top) and the second half (bottom) of the meme. The difference can be detected through the appearance of blue tears in Rashid's eyes to show that he was crying. In addition, Alignment (straight arrangement) is also seen in the production of the meme sample. This can be seen through the arrangement of images for Rashid's father on the left, while the image of Rashid was placed on the right as in Figure 4.5.

Next, the element of Simplicity can also be associated with the production of a background that is so simple without placing other additional images. This situation is seen as very accurate because it is able to help the readers to focus and to understand the main message conveyed in the meme. Apart from that, the element of Proximity is also detected, for example through the position of the first part and the second part placed close to one another. This situation is seen to be very helpful and make it easier for the readers to understand the message conveyed in the sample meme. In addition, the researchers also noticed that the meme sample used the element of Emphasis, for example in terms of the use of color on Rashid's eyes. This element is seen to be very effective in referring to Rashid's situation and health condition (having not enough sleep) as described in the meme. The element of Repetition can also be seen through the images of Rashid and Rashid's father in part one and part two. The two scenes are seen through a process of repetition until it appears that the scenes are almost the same.

\section{The Issue of World Cup 2018}

Sports issues could also be traced during the period. One of them was the 2018 World Cup football matches which took place in Russia from 14 June 2018 until 15 July 2018. There were several issues linked to memes involving 2018 World Cup. One of them was the issue of changing support for the competing teams. The change took place due to frustration of the supporters who could not accept the defeat of a team they supported before. The defeat had damaged the reputation and confidence of the supporters towards the team. This situation eventually led to a handful of supporters deciding to switch support to another team of another country.

In addition, issues related to the 2018 World Cup could also be linked to the ethics and culture displayed by the supporters of the competing teams. Such issues not only involved players who represented a competing country, but also involved supporters of a competing country. This situation could be observed through the way of social association and culture via the dressing etiquette on display. This is because, all actions and interactions which occurred would reflect on the culture and customs practiced by the individual, religion or country represented. On top of that, another identified issue related to the 2018 World Cup was the team spirit observed in the competing team. The team spirit and cooperation highlighted led to the existence of several memes in the form of motivation to the recipients.

This situation is an excellent and positive example to be practiced in daily life. Moreover, another related issue touched on the strong support given by a person to a country 
competing in the match. This can be explained through the actions of some supporters who were willing to restrain themselves from sleeping and waking up in the middle of the night and even into the morning just to watch the live match through the television screen and so on. The actions taken showed their high spirits and hopes for the chosen team and country. To identify issues in the 2018 World Cup more clearly, several elements were emphasized throughout the content analysis process which are color, character, typography and even meme layout. Based on the content analysis done, researchers found that the color element was often used in meme samples to display the issue of the football match. This situation can be explained through the use of flag colors for the competing countries, for example the green and yellow colors found on the flag of the Brazilian team. According to Lindgren and Jennifer (1997), red means power and speed in making decisions or actions, while yellow means joy and pleasure, being open-minded, having the desire to know something and can be associated with one's intelligence. The meaning of the color can be attributed to the presence of Brazilian fans who are so excited to support the team. In addition, the use of red is also able to reflect the physical and mental fitness of the players and their supporters.

Based on the sample of the memes studied, the researchers found that flag's symbol is not only used in issues related to political and administrative issues of a country, but also in issues involving sports with the intention to provide solid support to the team of choice. This can be observed through Rashid's meme who painted an image of the Brazilian flag on his right cheek as a sign of support for the team. This situation can be explained through the meme sample shown in the following Figure 4.6.

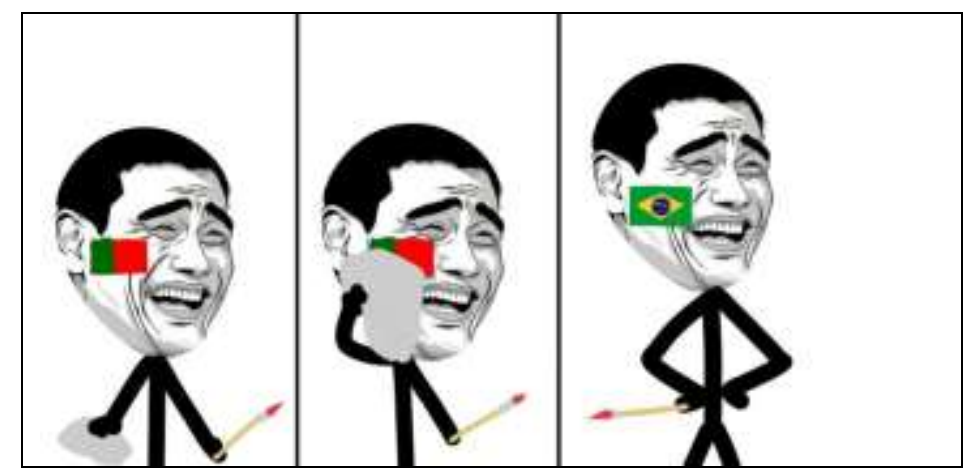

Figure 4.6: The issue of changing support in World Cup 2018

Based on the content analysis conducted, the researchers also found the existence of color changes on the flag. In the first half, the color of the flag was green and red, but upon entering the second half, researchers found that Rashid tried to delete the color of the flag and eventually replaced the color of the flag to green, yellow and blue as found in the colors of the Brazilian flag. The change in the color of the flag gave a certain meaning to the reader. According to the researchers, the change in the color of the flag could be attributed to the decision to change support for the team selected by Rashid.

This might be because Rashid realized that the Brazilian team had more advantages compared to the other team. This situation to some extent had influenced Rashid's thinking to change and finally choose the Brazilian team as the team of choice in the 2018 World Cup match. In addition, there were also some meme samples using various types of cheerful colors to show the liveliness of the atmosphere throughout the 2018 World Cup match. This diversity of colors can not only be seen through the background color of the meme sample, but also through the color of the character's clothing in the meme sample studied. This situation can 
be observed through a sample of memes selected from the Gags Malaysia's account as shown in Figure 4.7 below.

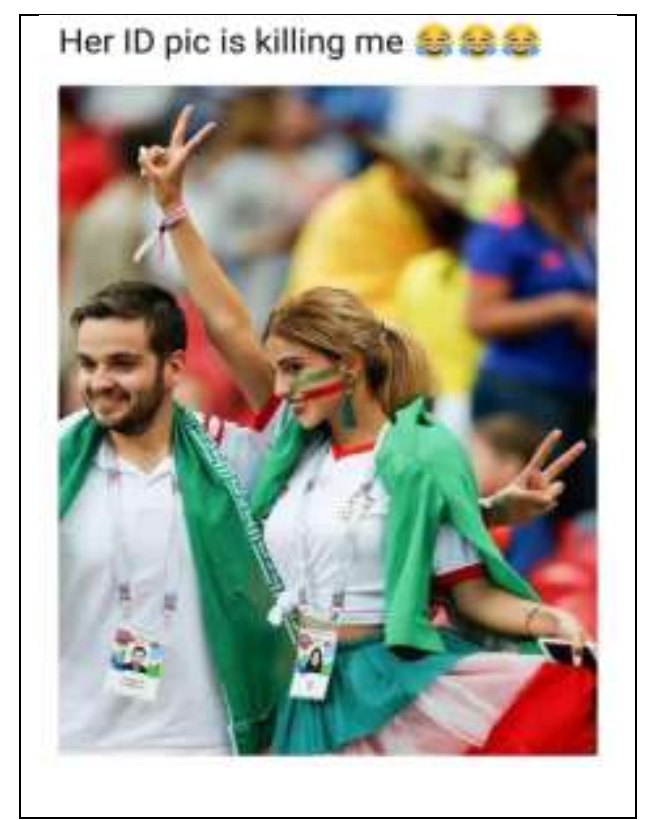

Figure 4.7: The issue of Iran supporters in sexy attire

Based on the meme sample in Figure 4.7 above, the researchers found that the clothing colors used by the male and female characters were red, white and green. The colors referred to the flag of Iran. The use of such colors indicates they have chosen the Iranian team as their team of choice in the 2018 World Cup match. The second element is character. Based on the meme samples studied during the period, the researchers identified the use of images and characters of leading international football players to illustrate the sports issues being displayed. This situation can be observed through the use of the characters of Cristiano Ronaldo and his friends in a sample of memes taken from the Gags Malaysia's Facebook account. Cristiano Ronaldo is a professional footballer originally from Portugal. Portugal was one of the countries competing in the 2018 World Cup. His prowess and agility when playing on the field meant his pictures are often included in a meme. One of them is a meme showing a picture of him chasing a bus to head to the 2018 World Cup match that took place. The meme shows the character of his teammates trying to provide assistance by extending a hand as a symbol of help as well as team spirit.

The situation can also be attributed to the spirit of cooperation, understanding and courage between them in achieving the mission and dream of winning every match they participated in. According to Goodwin, Piazza \& Rozin (2014), traits such as helpful and kind can be attributed to character categories that have high moral elements and high value of kindness. 


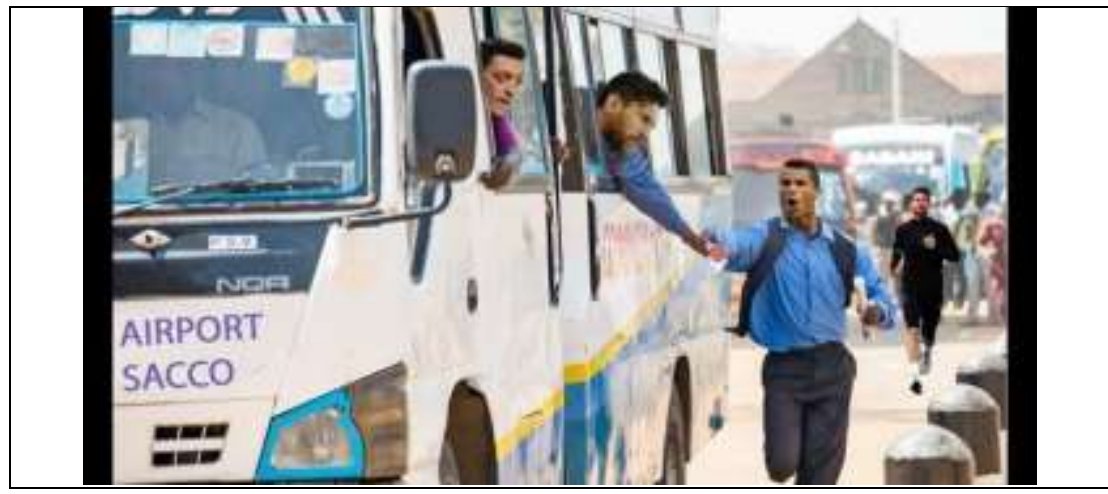

Figure 4.8: The issue of Cristiano Ronaldo and his teammates of Portugal national team

Issues related to the 2018 World Cup football can also be linked to the use of typographic elements i.e. the use of font types and designs in the selected meme samples. This situation can be attributed to the use of the word 'ID' to refer to a person's identity card as shown in the meme sample in Figure 4.7 previously. Identity card is commonly used as a medium to identify an individual to facilitate the identification process. With an identity card, a program will be easier to manage, for example in giving entry clearance to program committee members or spectators who have obtained tickets or clearance to watch the 2018 World Cup match. The use of the abbreviation of the word 'ID' is able to make it easier for the reader to understand the meaning to be conveyed in the sample meme. In addition, the use of the abbreviation is also seen as very beneficial because it can save the use of space to place letters or words to be displayed in the sample meme. However, despite the use of simple letters, there are also implicit messages and meanings that can be associated with the meme sample.

The implied meaning is in terms of culture and dress code for the Iranian woman. Based on the identity card used by the woman, she was a Muslim as it could clearly be seen that she was wearing a hijab in the photo in the identity card. The meaning implied did not only associate with the 2018 World Cup sports match, but also with the manners and dress code for a Muslim woman who was present to represent the country of Iran. As we all know, Iran is one of the countries which adopt the Islamic way of life. The situation in the meme has indirectly given meaning to the culture and way of life practiced by the Iranian woman. Moreover, typographic elements can also be associated with the selection of font sizes and colors used in the sample. The font size in the meme is seen to be so large to make it easier for the reader or audience to read the content of the message conveyed. This situation can be explained through the meme sample shown in the following Figure 4.9. 


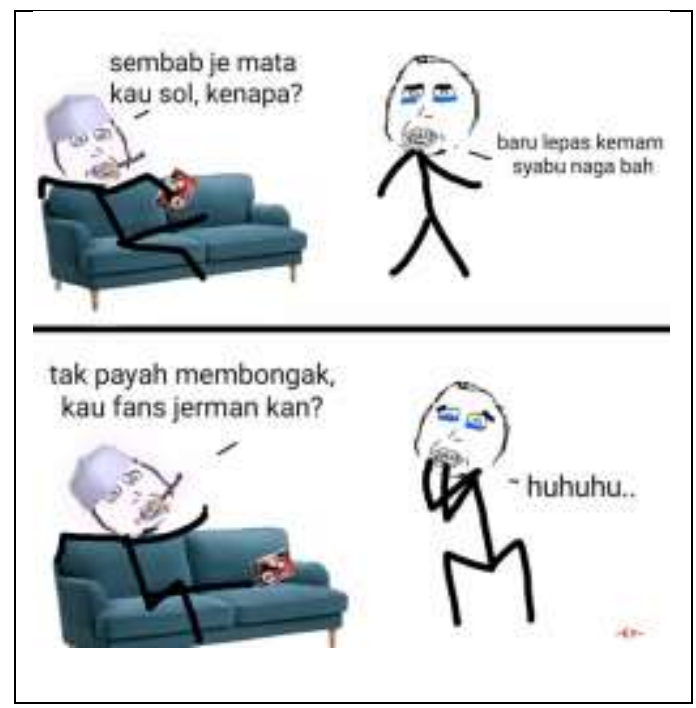

Figure 4.9: The issue of Germany supporters in World Cup 2018

Based on Figure 4.9, the researchers found that the font size used in Si Rashid's meme sample is not uniform. This is because, there are some words in the meme samples using large font sizes, while others use small-sized fonts. The font size difference may be intended to create a dialogue difference between Rashid and Rashid's father. According to the researchers, the use of large font sizes is more attractive because it is easier to read and understand. While small-sized fonts seem more difficult to read at long distances. In addition, the researchers also noticed that all the fonts used in the meme sample are black. The action is seen as very clever because it fits the background of the white meme and is able to make the words look clearer and easier for readers to read. However, the use of black fonts is not suitable when matched with dark backgrounds such as purple, red and so on. In terms of layout, the researchers found that the samples of memes studied explained the 2018 World Cup sports issues very well. This is because, there are some samples of memes edited using a computer to trigger a deeper impact to the readers. This situation can be explained through the face of Cristiano Ronaldo which has been pasted on top of another picture as shown in Figure 4.8 before. Cristiano Ronaldo is an international footballer who represents Portugal. The presence of the meme sample can be linked to the 2018 World Cup issue. The effects of the interesting layout and being produced using the superimpose technique make the meme sample seemed as if it is a real image. The situation is able to influence the understanding of readers to understand the issue of the 2018 World Cup more clearly.

Moreover, the researchers also found that the meme samples obtained in the issue of the 2018 World Cup sports matches can also be linked to the CASPER principle as previously explained. For the Contrast element, significant difference can be seen through the selection of red, green and yellow colors on Rashid's right cheek as in Figure 4.6. The change in the color of the flag on the right cheek is able to give meaning in relation to the change of team supported by Rashid in the 2018 World Cup match. On top of that, the element of Alignment (straight arrangement) can also be detected in the meme sample, for example in terms of processing and arrangement of scenes. The three scenes are arranged horizontally from left to right to reflect the storytelling conveyed in the meme sample. Moreover, for the Simplicity element, the researcher related the situation through a white background as in the meme sample in Figure 4.6 and 4.9. Both meme samples only use white background to make it easier for readers to understand the real message being conveyed in the meme sample more clearly. 
On the other hand, the element of Proximity can also be seen very clearly in the sample meme, where all scenes have been arranged closely to make it easier for readers to understand the storyline of each scene more clearly, easily and effectively. Meanwhile, the Emphasis element can be attributed to Rashid's image which looks bigger in the third half than the first and second half as shown in Figure 4.6. The large size of Rahid's image in the third scene is seen to be able to create a significant element of emphasis between the scenes. As for the Repetition element, the researchers found that most of the meme samples obtained from Rashid's meme used this element, for example in Figure 4.6 and 4.9 shown previously. Each scene featured contains an element of repetition in terms of its character, color, main image and background. However, the difference in the message conveyed in each scene can be seen through the addition of word text or the use of additional elements such as color and other side images, for example the position of wooden pencil for different Rashid memes in scene two and three as in Figure 4.6.

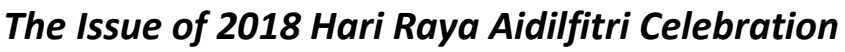

The issue of Aidilfitri celebrations can also be identified through the meme samples analyzed. The festival is celebrated by Muslims around the world every year after a month of fasting. In this case, the celebration was celebrated on 14 June 2018. Based on the Aidilfitri 2018 celebrations, several issues were successfully identified in the sample of memes shared during the period. The issue referred to the situation of people who had to celebrate the festival alone. The grief felt was applied in the meme samples obtained during the period. Apart from that, another issue raised was the preparations made by the Muslim community during the celebration, for example the preparation in terms of cuisine and clothing that is usually done every time the festival takes place. Some memes involving local celebrities were made in regards to the issues of this festival to attract the attention of readers to read the memes.

To identify issues related to the Aidilfitri 2018 celebration, researchers have emphasized four important elements throughout the content analysis, namely color, character, typography and layout. As for the color element, the researchers found that green was often the color chosen. This situation can be explained through the selection of light green color in the meme sample shown in Figure 4.10 below.

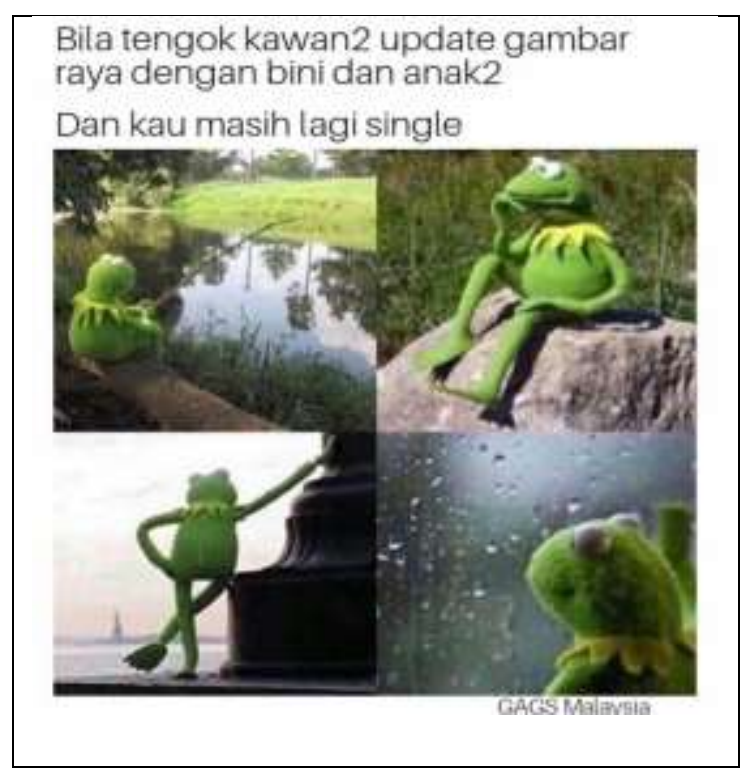

Figure 4.10: The issue of celebrating 2018 Aidilfitri alone 
According to Lindgren and Jennifer (1997), light green means growth, hard work, ambition, strength and empathy. This situation can be attributed to Islam which encourages its followers to always maintain manners and ethics in social association, for example speaking gently when dealing with older people and so on. Moreover, the choice of light green color can also be attributed to one's inner strength. This situation can be explained through the strength of a person when tested by Allah S.W.T with various trials of life, for example those who are late in getting married. The meaning constructed through the meme sample in Figure 4.10 above also shows a person's feelings of sadness and loneliness when having to celebrate Aidilfitri alone. The second element is in terms of character. Samples of memes studied during the period were also detected to contain animal characters and cartoon animations. The animal character used is a silent frog. The situation is intended to describe the emotions of a person who has to celebrate Hari Raya Aidilfitri alone because he or she is still single and has no family. This situation can be attributed to the meme sample in Figure 4.10 which displays a person's hope to celebrate the festival with his or her own spouse and family.

In addition, researchers also found the existence of the use of Malaysian celebrity characters. The celebrity in the image is Aiman Tino, a new local singer who was rising and actively forging his name in the Malaysian entertainment industry. The situation can be proved through the meme sample shown in the following Figure 4.11.

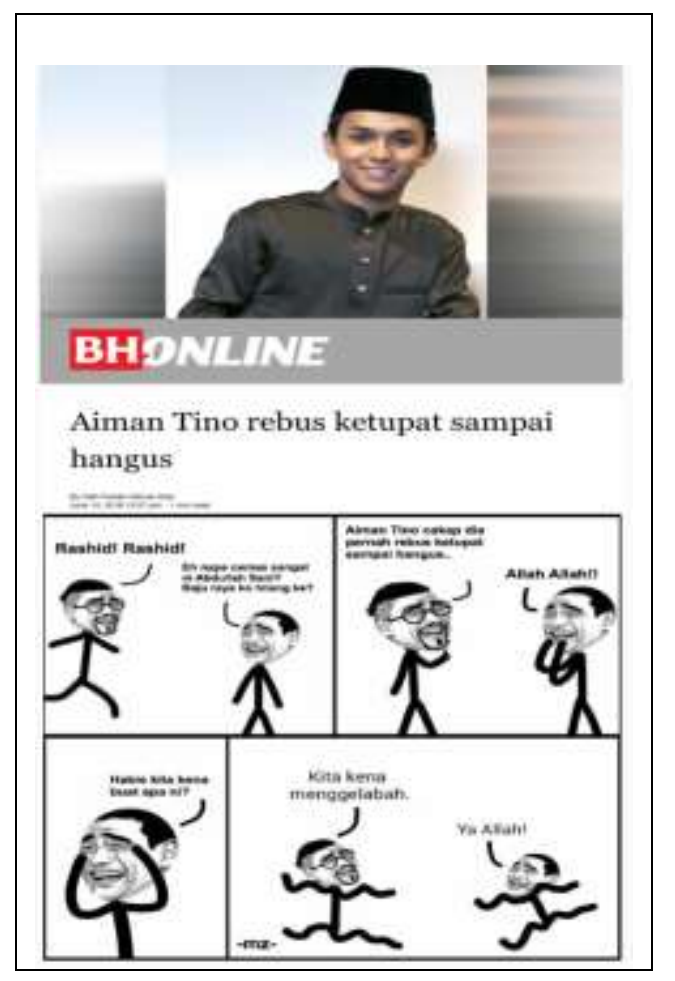

Figure 4.11: The issue of Aiman Tino boiling ketupat (traditional rice pack) until it was burnt

Based on the meme, he is styling traditional Malay clothing with black songkok (head cover). The dress is commonly used by Muslim men in Malaysia when celebrating Hari Raya Aidilfitri or other festivals synonymous with the Muslim community. The way it is used indicates its relation to issues that are happening within the festival period, namely the celebration of Hari Raya Aidilfitri 2018. On the other hand, another of the celebration issue touched on is the dishes that are often served by the Muslim community in Malaysia when celebrating the 
festival, i.e. ketupat. Usually, ketupat will be eaten with peanut gravy and rendang either when eating with the family at home or during an open house banquet. However, the explanation of ketupat is only explained through sentences and words, without giving examples and actual images of the food. Other than the color and character elements, the researchers also managed to identify typographic elements in a sample of memes studied. Typographic elements can be detected through the font size and color used in the meme samples. Based on issues related to the Hari Raya Aidilfitri 2018 celebration, samples of memes studied during the period are seen to be using large font size as shown in Figure 4.10 and 4.11 previously. The large font size selection technique is effective in making it easier for the audience to read the meme samples obtained.

Additionally, the choice of black font color is also suitable. The black color selection is very effective when paired with a white meme background. This is because, not all colors are suitable to be paired with a white background, for example yellow. The selection of yellow font will interfere with the clarity of the wordings if displayed on a white background. According to Abdullah (2018), one of the disadvantages of white is being striking enough to cause eye and head discomfort or pain to a person if the color is more dominant compared to other colors. In addition, layout element can also be witnessed in the sample of memes studied. Based on the researcher's observation on the meme sample obtained during the period, the layout element in the meme samples highlighting the issue of Hari Raya Aidilfitri also emphasizes the CASPER principle as discussed previously. This situation can be explained as follows. For the Contrast element (significant difference), the researchers found that the principle can be proven through a combination of real human images with cartoon facial and body images as can be seen in Figure 4.11. Apart from that, the image of celebrity Aiman Tino was also displayed. To make the meme sample looking more interesting, a combination of animated elements was also incorporated in the meme sample, for example a cartoon picture of Rashid with a skewer-like body shape. This situation is very helpful in the storytelling process in the meme sample. Alignment element (straight arrangement) can be observed through the position of the image of Rashid in each scene as in Figure 4.11. The position of Rashid's character was drawn in a straight position to make it easier for the reader to follow the story and the message being conveyed, for example in relation to the issue of Hari Raya Aidilfitri 2018 celebration.

As for the Simplicity element, the use of the principle can be proven through the selection of colors in the meme sample. Black and white were chosen as the main colors in the production of the meme. Despite being plain, the simplicity in the selection of colors makes it more convenient for the readers to more effectively understand each message being highlighted in the meme sample. In addition, for the Proximity element, the researchers found that each scene in Figure 4.10 was arranged so closely. This is to make it easier for the reader to follow the story sequence being told in each scene. Some images were also displayed in a close-up to create variety in the scenes. Besides, the element of Emphasis was also detected in the meme sample to explain issues related to Aidilfitri 2018, for example Aiman Tino's face size looks larger compared to Rashid's face size in each scene as shown in Figure 4.11. This situation is able to attract the reader's attention and gives an idea of the issue or message being conveyed. As for the element of Repetition, the element can be seen through Rashid's face. All of Rashid's faces have been repeated, however in different circumstances and positions according to the suitability of the scene. Based on the content analysis, the researchers found that the memes produced within the period of May 1, 2018 to July 31, 2018 focused more on the current issues that occurred during that period, namely the issue of 14 th 
General Election (GE-14), international football matches of World Cup 2018, and the celebration of Aidilfitri 2018. The meme samples produced during the period intended to convey the current situation occurring in relation to the incident or event being highlighted.

\section{Discussion}

Based on the observation of meme samples in this study, researchers have successfully identified several issues often transmitted from May 2018 to July 2018. The issues were the 14th general election, 2018 World Cup matches, and 2018 Aidilfitri celebration. Researchers found that the memes transmitted during the period were more about current issues that were happening, both domestically and abroad.

Based on the content analysis conducted, the researchers found that there is a very significant relationship between the elements of color, character, typography and meme layout with the current issues occurring at that time. All of these intended elements have greatly aided researchers in identifying current issues that occur and are often spread using memes. One of the elements detected in a meme sample is color. Color is not only used to produce attractive images on the picture, it is also applied in the selection of letters and alphabets. The color element has a certain impact to the information being conveyed in the memes. The use of color can refer to the use of color for flags, clothing, backgrounds, environment and so on. The use of color is seen to be able to attract the attention of the audience to discover an information content either in terms of pictures or words.

Furthermore, character elements are also given attention in the content analysis process carried out. Researchers found that all samples of memes studied during the period had used character elements to ensure that the message could be conveyed more effectively. The characters used are not only in the form of real pictures, but also in the form of cartoons, animations and even animals. The use of a character provides a clear picture of an issue or the content of the information conveyed. The next element refers to a typographic point of view, i.e. in terms of the typeface and font size used in the meme sample. Based on the observations, researchers found that most of the samples of memes studied used large font of more than size 12 . This situation aims to provide a clearer message and makes it easier for readers to understand the information being conveyed. In addition, the use of font size also varied between the meme samples. Moreover, the choice of font size also depends on the message to be highlighted, where large font sizes are often used for important words or sentences, for example through the headline and so on. This situation aims to make it easier for the reader to understand in more depth, the literal and implicit meaning being conveyed.

Moreover, the meme samples mostly used black and white font colors. The color selection is seen to be very suitable for any visual background used in the sample. In addition, there are also wordings in bright colors such as red to evoke an element of emphasis. According to Lindgren and Jennifer (1997), the color red means accepting challenges, power and swift actions. This condition can be attributed to one's power and abilities, whether in the field of leadership and so on. Furthermore, the selection of red color is also able to give a deeper impact on the content or issue being conveyed. The choice of size and color on the font can also be linked to the principle of construction and presentation known as the CASPER technique (Multimedia Exploration Module: 30). The CASPER principle is often applied in the process of designing a meme. This situation can be seen through the results of content analysis on a sample of memes read. Neat layout will allow the audience to understand an issue more easily and clearly. There are also some memes produced using a combination of 
real images with animated images such as cartoons or even animals. This situation will have a deeper impact on the message conveyed.

All these elements greatly help the researchers in determining the current issues and messages in the selected meme sample. With the elements of color, character, typography and layout, the researchers could determine the idea and content of information being conveyed in a meme. This situation could indirectly help researchers in making comparisons between each meme sample to determine current issues conveyed from May 2018 to July 2018. After making observations, researchers found that most of the issues highlighted from May 2018 to July 2018 were closely related with current issues, such as the issue of the 14th General Election, international level football matches (World Cup, 2018) and the celebration of Hari Raya Aidilfitri 2018. All three issues were more dominant compared to other issues during that period. Therefore, researchers have concluded that the issues associated in a meme are also influenced by factors such as current situations or events. The situation had indirectly affected the formation of a meme and issues to be conveyed to readers. Based on the findings of the study obtained in this section, researchers also found that the media system is able to influence a person to continue to rely on a media in obtaining the necessary information. In this content analysis method, among the aspects that can be associated with the media system are the use of color, character, typography and also the layout display. All these aspects will facilitate a person in the process of constructing meaning and identifying the meaning being implied after reading the meme.

\section{Conclusion}

According to Stuart Hall (1980), a text is polesemic, where a text is able to convey various meanings. Therefore, each individual will have different interpretations and opinions on something he or she experienced. Since a text can have a variety of meanings, therefore people may have different perceptions on the issues portrayed in memes. The process of meaning formation of a meme can provide answers to the issues being highlighted at that time. Limor (2014: 342) stated that the meme genre is not fixed, where it depends on the social, political or technological situation in a country. This is seen to have similarities with the issues being spread over a period of time. In the content analysis conducted, the researchers found that the issues that went viral through memes are actually quite similar to the opinion being given by Limor. The issues in a meme can change depending on the context and current issues occurring. Therefore, the researchers argue that the current situation and circumstances are seen as important factors in the formation of an issue. Based on the sample of memes obtained, the researchers think that most of the issues that exist are related to the current situation. As the meme sample collection period occurred between May 2018 to July 2018, the issues were limited to current events and situations occurring during that period only, such as the 14th General Election, New Malaysia issues, international football match issues (World Cup, 2018) and the celebration of Hari Raya Aidilfitiri 2018. These situations coincide with the opinion of Mehrad and Yousefi (2018) who stated that a person will depend on media when a current issue arises, for example during times of turmoil, crisis or natural disasters. An individual will rely on media to obtain the latest information on something that is happening. This situation can be attributed to the production of memes that are widely shared through social media when an issue occurs whether inside or outside of the country. 


\section{References}

Hamzah, A. (2007). Satu kajian skema taakulan akhlak dalam kalangan pelajar Melayu. Tesis ljazah Doktor Falsafah. Universiti Sains Malaysia.

Akashdeep B., Vinay, A., \& Sam, G. (2017). Impact of Social Networking on Indian Youth- A Survey. International Journal of Electronics and Telecommunication. Vol.7, No.1, pp.4151, September 2017. DOI: 10.6636/IJEIE.201709.7(1).05.

Anon. (2016). Seloka Sindiran Rashid. Harian Metro. 16 January http://psasir.upm.edu.my/43291/ [1

September 2017]

Ball-Rokeach, S. J., \& DeFleur, M. L. (1976). A Dependency Model of Mass-Media Effects. Communication Research.

Ball-Rokeach, S. J. (1985). The Orgins of Individual Media-System Dependency: A Socialogical Framework. Communication Research 12(4): 485-510.

Bedu, H., Katip, K., Sahid, F., \& Mansor, S. (2008). Keruntuhan akhlak dan gejala sosial dalam keluarga; isu dan cabaran. Seminar Kaunseling Keluarga 2008. Skudai: Fakulti Pendidikan, Universiti Teknologi Malaysia.

Dawkins, R. (1976). The Selfish Gene. New York: Oxford University Press.

Anuar, F. N., Ahmad, F., \& Mohamed, S. (2017). Konstruksi Meme di Laman Sosial Terhadap Isu Semasa. Journal of Social Science and Humanities. Special Articles (Disember, 2017): 001 ISSN: 1823-884x

Foster, B. J. (2012). It's All in a Meme: A Content Analysis of Memes Posted to 2012 Presidential Election Facebook Pages. Tesis Sarjana. University of Arkansas.

Foster, B. J. (2012). It's All in a Meme: A Content Analysis of Memes Posted to 2012 Presidential Election Facebook Pages. Tesis Sarjana. University of Arkansas.

Goodwin, G. P., Piazza, J., \& Rozin, P. (2014). Moral Character Predominates in Perception and Evaluation. Journal of Personality and Social Psychology. Vol. 106, No.1, 148-168. Issue on Internet Memes. (2014). Journal of visual culture. Vol 13(3): 248-252 DOI 10.1177/1470412914551351. SAGE Publications.

Mehrad, J., \& Yousefi, Z. (2018). Introdusing the Theory of “Media System Dependency" with Emphasis on its Potential Application in Theoretical Framework of Researches in the Field of Information Science and Knowledge. International Journal of Information Science anda Management. Vol. 16, No. 1, 2018, 1-14.

Kamus Dewan Edisi Baru. (1992). Kuala Lumpur: Dewan Bahasa dan Pustaka.

Lauren, S., Moira, B., \& Steven, W. (2016). What's in a Like? Attitudes and behaviors around receiving Likes on Facebook. Session: Museums and Public space. CSCW' 16, February 27- March 2, 2016. San Francisco, CA, USA.

Laine, N., \& Laura, P. S. (2014). One Does Not Simply: An Introduction to the Special

Lindgren, C. E., \& Jennifer, B. (1997). Aura Awareness. California: Progen Co. Malaysian Administrative Modernisation and Management Planning Unit 2015.

Ryan, M. M. (2012). The World Made Meme: Discourse and Identity in Participatory Media. Doctor of Philosophy Thesis. University of Kansas.

Richard, F., Alessio, C., Lucas, G., \& Rasmus, K. N. (2018). Measuring the reach of 'fake news" and online disinformation in Europe. Oxford: Reuters Institute for the study of journalism.

Sangeet, K. (2015). Contagious memes, viral videos and subversive parody: The grammar of contention on the Indian web. The International Communication Gazette. Vol. 77(3) 232-247. SAGE Publications. 
Serazio, M. (2008). The Apolitical Irony of Generation Mash-Up: A Cultural Case Study in Popular Music. Popular Music and Society 31(1): 79-94.

Mustafa, S. E., \& Hamzah, A. (2010). Laman sosial: Tinjaun Terhadap Laman Sosial dalam Talian Tempatan. Jurnal Pengajian Media Malaysia. 12(2): 37 - 52.

Shifman, L. (2014). The Cultural Logic of Photo- Based Meme Genres. Journal of Visual Culture 13(3): 340-358.

Shifman, L. (2011). An Anatomy of a Youtube Meme. New Media \& Society. Sage Publications Ltd

Hamid, S. H. (2016). Pengaruh Media Massa Terhadap Perbahan Sosial Masyarakat. Journal of Social Science and Humanities. Special Issue 1 (October 2016) pp: 214-226. ISSN: 1823-884x.

Suzan, M. R., Jane, M. C., \& Terry, A. B. (2018). Two strategies for qualitative content analysis: An Intramethod approach to triangulation. Sage Publication. DOI: $10.1177 / 1049732317753586$.

Hall, S. (1980). Media, Culture \& Society. Academic Press Inc. London. Suhaimee

Shifman, L. (2014). The Cultural Logic of Photo- Based Meme Genres. Journal of Visual Culture 13(3): 340-358.

Sannusi, S. N., \& Fauzi, N. M. A. (2017). Analisis Berita Kempen Calon Pilihanraya Presiden Donald Trump: Kajian terhadap Utusan Malaysia Online dan Astro Awani Online.Jurnal Komunikasi. Jilid 33 (1): 460-474. 